\title{
A QUESTÃO DO ENSINO SUPERIOR NOS ESTADOS UNIDOS*
}

\author{
Maria Ribeiro do Valle ${ }^{1}$
}

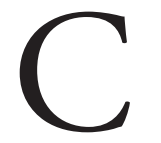

om uma pesquisa exaustiva sobre o sistema de educação superior norte-americano, Reginaldo C. Moraes traz dados consistentes a respeito tanto da superfície visível e imediata da história da sociedade quanto da "corrente subterrânea" das suas transformaçôes socioeconômicas em longo prazo. Educação e sociedade como duas faces de um mesmo processo que é analisado diacrônica e sincronicamente, por meio de suas dinâmicas quantitativas e qualitativas. A partir da compreensão da estrutura e da história desse instigante e ou intrigante sistema educacional, que até hoje norteia os parâmetros do ensino universitário em vários países, Moraes não perde de vista a história de sua constituiçáo lançando luz ao sistema educacional, erigido como um dos pilares institucionais que caracterizam e sustentam a secular "democracia na América".

A análise sobre o sistema de educação norte-americano é dividida em cinco fases: do começo de Independência até a Guerra Civil; da Guerra Civil (1861-1865) e do primeiro Morrill Act (1872) até 1920; de 1920 a 1945 "primeiro ensaio de massificação e modelagem do sistema de educação superior”; de 1945 a 1970 — os chamados "25 anos gloriosos do pós-guerra"; e, finalmente, de 1980 até os nossos dias. Ao trilhar esse caminho, o autor pôde identificar quais os desafios em cena e, muitas vezes, supostamente conflitantes, como o de formar as elites, incorporar os imigrantes pela assimilação cultural e garantir a qualificação da força de trabalho. Assim como também buscou elucidar questóes como a influência de grupos protestantes e católicos na educação norte-americana, a criação de escolas superiores públicas paralelamente ao predomínio de escolas privadas em determinadas regiōes, métodos de ensino, discussão a respeito de disciplinas obrigatórias ou eletivas, a incidência das cidades, indústrias, migrantes e imigrantes na educaçăo universitária, os surtos de massificação, as fundaçóes filantrópicas, a política federal para a educação superior, o crescimento de matrícula, o contraste entre as convicçôes dos "líderes" e as tendências da sociedade norte-americana, os novos públicos para a educação superior, o papel dos "protetores"

\footnotetext{
*Resenha do livro MORAES, Reginaldo C. Educação Superior nos Estados Unidos. São Paulo: UNESP, 2015.

${ }^{1}$ Universidade Estadual Paulista "Júlio de Mesquita Filho" (UNESP), Faculdade de Ciências e Letras, Departamento de Sociologia - Campus de Araraquara - Araraquara (SP), Brasil.

E-mail: maria.ribeiro.valle@uol.com.br

DOI: 10.1590/ES0101-73302016157833
} 
das universidades de elite, a descentralização como fator de inclusão, dentre outros. $\mathrm{O}$ autor traz também os estudos de casos dos Community Colleges, emblemáticos do ensino superior americano, nas suas mais diversas nuances devido aos diferentes contextos históricos em que emergem e por que vigoram ou não. Essa gama de questôes, elencada assim, atemporalmente, até mesmo dessa forma, faz sentido aos desafios da educação superior hoje, independentemente de sua a circunscrição a um determinado país? Efeitos da globalização? Do papel imperial exercido pelos Estados Unidos da América (EUA) desde os primórdios de seu sistema educacional? Enfrentar essas questóes é fundamental para que possamos perceber a possibilidade de um redesenho - ou não - das instituiçóes educacionais que se constituem e mantêm dialogando diretamente com o poder público, não raras vezes obtendo sucesso em seus propósitos.

É importante ressaltar que o trabalho do autor não é uma explanação de temas que, embora se sobreponham, são recorrentes, mesmo que muitas vezes com novas roupagens, em períodos históricos distintos, o que temos agora é acesso a um estudo sistemático, estatístico, qualitativo e rigorosamente historicizado do ensino superior norte-americano, circunscrito na realidade histórica dos EUA. Contudo, é difícil resistir a ler todos esses estudos sem ver neles o que somos ou no que nos tornamos, identificando faces de nossa educação e sociedade mundialmente globalizadas.

Nesse sentido, é emblemática a integração das ciências e das técnicas ao velho ensino liberal clássico desde o século XIII (nos EUA) parecer-nos como uma constante náo apenas no ensino superior americano, mas na agenda contemporânea das discussōes e práticas de políticas educacionais governamentais do Brasil inseridas no quadro desolador pautado pela virulência empregada no ataque às conquistas sociais da população e das instituiçóes econômicas e científicas autônomas. Como aborda em suas reflexóes finais, apesar de a ideia de que a escola possa curar a pobreza seja amplamente recitada por políticos, a realidade norte-americana tem sido prova de como ela é paradoxal.

Certamente essa não é a única contribuição da pesquisa do professor Reginaldo Moraes, mas ela apresenta fartos subsídios teóricos e históricos para que possamos enfrentar tal cenário. Com os ensinamentos de Patrizia Piozzi, ouso aqui parafraseá-la para concluir esta resenha: Moraes, "desencavando motivos, ideias, interesses" que movimentam a educação superior nos EUA, quiçá no Brasil e em grande parte do mundo, ajuda-nos "a superar a dimensão do dado, a traçar paralelos e a redescobrir no futuro um horizonte de possibilidades". Oxalá a compreensão da constituição e da história da educação superior dos EUA aponte-nos, ainda que pelo seu avesso, um caminho outro!

Recebido em 16 de dezembro de 2015.

Aprovado em 29 de janeiro de 2016. 